\title{
PENGEMBANGAN PROGRAM BIMBINGAN KELOMPOK TENTANG KESIAPAN BERWIRAUSAHA PADA SISWA SMA DI KABUPATEN KUBU RAYA
}

\author{
Novi Andriati \\ Program Studi Bimbingan dan Konseling \\ Fakultas Ilmu Pendidikan dan Pengetahuan Sosial IKIP PGRI Pontianak \\ Jalan Ampera Nomor 88 Pontianak - 78116, Telepon (0561) 748219 Fax. (0561) 589855 \\ Alamat e-mail: Novieandriaty@yahoo.co.id

\begin{abstract}
Abstrak
Tujuan penelitian yaitu menghasilkan program bimbingan kelompok tentang kesiapan berwirausaha siswa SMA. Dari hasil penelitian, dapat disimpulkan bahwa program bimbingan kelompok efektif untuk meningkatkan kesiapan berwirausaha siswa. Penggunaan program bimbingan kelompok tentang kesiapan berwirausaha siswa sebaiknya dapat dimulai dengan mendiagnosa secara cermat kondisi objektif siswa yang akan dijadikan sebagai anggota kelompok sebagai dasar perlakuan mengandung nilai kebermanfaatan dan kebermaknaan bagi siswa SMA serta guru dapat menggunakan program bimbingan kelompok untuk meningkatkan karier siswa SMA.
\end{abstract}

Kata Kunci: program bimbingan kelompok, kesiapan berwirausaha, siswa

\begin{abstract}
The purpose of research is to produce counseling group program about the student business entrepreneurship readiness in high School. From the results of the research, it can be concluded that a counseling group program is effective to enhance the readiness of entrepreneurship students. By using the counseling group program about student business entrepreneurship readiness should be able to start with the diagnose can conditions objective students will serve as members of the group an basic treatment contains the value of the usefulness and meaningfulness for high school students as well as teachers can use the counseling group program to enhance the careers of high school students.
\end{abstract}

Keywords: group counseling program, business entrepreneurship readiness, Student

\section{PENDAHULUAN}

Pendidikan kewirausahaan bertujuan untuk membentuk manusia secara utuh (holistik), sebagai insan yang memiliki karakter, pemahaman dan ketrampilan sebagai wirausaha (Kasmir: 2014). Pada dasarnya, pendidikan kewirausahaan dapat diimplementasikan secara terpadu dengan kegiatan-kegiatan pendidikan di sekolah. Pelaksanaan pendidikan kewirausahaan dilakukan oleh kepala sekolah, guru, tenaga kependidikan (konselor), peserta didik secara bersama-sama sebagai suatu komunitas pendidikan. Pendidikan kewirausahaan diterapkan ke dalam kurikulum dengan cara mengidentifikasi jenis-jenis kegiatan di sekolah yang dapat merealisasikan pendidikan kewirausahaan dan 
direalisasikan peserta didik dalam kehidupan sehari-hari. Wirausaha merupakan inovator yang mampu memanfaatkan dan mengubah kesempatan menjadi ide yang dapat dijual, dipasarkan, memberi nilai tambah dengan memanfaatkan upaya, waktu, biaya, kecakapan dengan tujuan mendapatkan keuntungan. Dari segi karakteristik perilaku, wirausaha (entrepreneur) adalah yang mendirikan, mengelola, mengembangkan, dan melembagakan perusahaan miliknya sendiri. Wirausaha adalah yang dapat menciptakan kerja bagi orang lain dengan berswadaya. Wibowo, (2005) mengemukakan melalui bimbingan kelompok siswa dapat mengembangkan sikap dan membentuk perilaku yang lebih baik, mampu mengembangkan keterampilan sosialnya dalam dinamika kelompok seperti saling bekerjasama, saling memahami satu sama lain, mampu menyampaikan pendapatnya, mampu menghargai dan menerima pendapat anggota kelompok dan membantu menyelesaikan permasalahan yang dihadapi oleh anggota kelompok lainnya.

Therapeutic Factors in Group Counseling: Implications for Audiologic Rehabilitation (Sue Ann Erdman: 2008), menyatakan bahwa bimbingan kelompok dapat efektif dalam memberikan efek terapheutic pada indivdu dikarenakan dalam bimbingan kelompok memiliki asas yang universal dalam menghargai keberagaman dan kebersamaan dalam membahas sebuah topik penugasan serta mampu memberi dampak membangun harapan baru sesama anggota kelompok untuk menciptakan pemahaman dan pengetahuan baru yang tidak terbatas pada masalah pribadi melainkan juga masalah sosial, belajar, dan karier. Jurnal penelitian berjudul Pelatihan Teknik-teknik Bimbingan Kelompok Menggunakan Latihan Kelompok (Nandang Rusmana, 2008), menyatakan bahwa,"penggunaan bimbingan dan konseling kelompok merupakan hal yang esensial dan bersifat preventif serta edukasional yang bermuara pada dua sumber utama yaitu teori kepribadian dan dinamika kelompok". Sejalan dengan penelitian tersebut Model Bimbingan Kelompok berbasis Budaya Hibua Lamo Untuk Meningkatkan Kecerdasan Sosial Siswa (Jerizal Petrus: 2012), menyatakan bahwa melalui bimbingan kelompok setiap anggota kelompok diajak untuk mencapai pemahaman akan upaya-upaya pemecahan masalah sosial yang berkenaan dengan 
nilai-nilai etika sosial budaya yang ada di lingkungan keluarga, sekolah, dan masyarakat. Berikut adalah beberapa penelitian terdahulu yang memiliki relevansi dengan penelitian ini. Penelitian terdahulu yang relevan bisa dijadikan acuan dalam mengembangkan penelitian yang baru terkait dengan tema dan atau pokok bahasan yang sama. Penelitian terdahulu itu antara lain :

Penelitian tesis Dodi Priyatmo Silondae (2013) yang berjudul Model Bimbingan Kelompok Berbasis Nilai Budaya Suku Tolaki Untuk Meningkatkan Keterampilan Siswa, menyebutkan bahwa guru bimbingan dan konseling perlu memperhatikan nilai-nilai kebudayaan dalam menyelenggarakan bimbingan kelompok, mengingat yang menjadi objek layanan tersebut adalah siswa sebagai individu yang sedang berkembang (becoming), dan salah satu hal yang mempengaruhi perkembangan individu adalah kebudayaan dimana individu tersebut berasal. Berikutnya adalah penelitian berjudul Bimbingan Kelompok Untuk Mencerdaskan Kecerdasan Emosional Siswa (Nuraniningsih, 2011), yang menyebutkan bahwa individu mampu mengembangkan kecerdasan emosionalnya secara baik apabila dapat difasilitasi secara efektif dalam sebuah layanan yang melibatkan aspek afeksi, kognisi, dan cara berperilaku yaitu dalam sebuah layanan bimbingan kelompok.

Aydin, D. 2009. Efectiveness Of A Group Guidance Program On Realistic Study Field Choice Among First Year High School Students. Penelitian ini terbukti bahwa bimbingan kelompok dapat meningkatkan motivasi semua target populasi yaitu membantu meningkatkan motivasi siswa dalam melakukan pilihan bidang studi pada tahun pertama sekolah, secara tidak langsung penelitian ini mempunyai tujuan yang sama yaitu selalu meningkatkan motivasi juga meningkatkan kepercayaan diri siswa. Driessens. 2004. Integrating Guidance into Relational Reinforcement Learning. Kluwer Academic Publishers: Manufactured in The Netherlands. Penelitian ini dilaksanakan dalam menganalisis kemampuan siswa belajar melalui bimbingan klasikal. Bimbingan yang diberikan diharapkan siswa bisa memahami tentang pentingnya pengulangan kembali materi yang diberikan oleh guru untuk dilaksanakan dalam proses pembelajaran selanjutnya. Melalui penelitian ini, bimbingan klasikal efektif sebagai analisa kemampuan 
siswa dalam belajar. Hoifodt \& Talseth. 2006. A Qualitative Study Of The Learning Processes In Young Physician Streating Suicidal Patients: From Insecurity To Personal Pattern Knowledge And Self-Confidence. BMC: Psychiatry. Penelitian ini adalah bentuk bimbingan kelompok dalam proses pembelajaran oleh seorang mahasiswa kedokteran dalam mengahadapi pasien yang bunuh diri. Pembimbingnya yaitu seorang dokter menceritakan pengalaman hidupnya sendiri. Cara menangani pasien yang depresi dan tidak memiliki konsep diri sehingga. Melalui penelitian ini, bimbingan klasikal efektif untuk mengatasi pasien yang ingin bunuh diri.

Helen, Charles \& Kuruvilla Joseph. 2011. Effectiveness Of Group Counseling On The Level Of Self-Esteem Of Adolescent School Girls. Nursing trendz. Penelitian ini menyebutkan bahwa masa remaja adalah masa transisi dimana adanya perubahan dari masa anak-anak menuju masa dewasa, pada masa ini banyak gejolak atau perubahan-perubahan yang dialami oleh remaja. Pada masa ini tidak sedikit remaja putri yang berperilaku negatif karena pengaruh lingkungan seperti putus sekolah dan melakukan free sex sehingga banyak gadis yang hamil. Rendahnya kepercayaan diri pada remaja mengakibatkan mudahnya remaja terbawa pengaruh negatif karena tidak yakin akan dirinya. Melalui penelitian eksperimen ini terbukti bahwa konseling kelompok efektif meningkatkan kepercayaan diri pada remaja putri.

Dalam proses menumbuhkan kesiapan berwirausaha, siswa memerlukan bantuan untuk melaksanakan proses tersebut, bantuan tersebut dapat dilaksanakan oleh guru BK dengan membuat program bimbingan kelompok yang merupakan wadah penyaluran untuk melaksanakan program yang telah dibuat. Selain itu, diketahui bahwa siswa Sekolah Menengah Atas Kabupaten Kubu Raya mengalami masalah kurang percaya diri, kurang berani mengambil resiko, kurangnya rasa kepemimpinan, kurang berorientasi pada tugas dan hasil, tepatnya masalah dalam menumbuhkan kesiapan berwirausaha. Kesiapan berwirausaha merupakan aspek yang penting karena mampu menjadi stimulus yang mendorong siswa untuk mampu menyiapkan diri kedunia kerja. Namun kenyataannya tidak semua siswa dapat menumbuhkan kesiapan berwirasaha sejak masa sekolah 
sehingga membutuhkan trik ataupun cara dalam menumbuhkan kesiapan berwirausaha. Oleh karena itu, berdasarkan kondisi tersebut merupakan salah satu alasan peneliti ingin mengadakan penelitian berjudul "Program Bimbingan Kelompok Tentang Kesiapan Berwirausaha pada Siswa SMA di Kabupaten Kubu Raya" dengan harapan bahwa program bimbingan kelompok dapat mempersiapkan siswa dalam menghadapi dunia usaha.

\section{METODE}

Metode penelitian ini menggunakan pendekatan penelitian dan pengembangan (research and development). Produk yang dimaksud dalam penelitian ini adalah sebuah program bimbingan kelompok untuk mempersiapkan kewirausahaan siswa SMA. Kerangka isi dan komponen program disusun berdasarkan kajian konsep bimbingan kelompok, kajian konsep kewirausahaan serta kajian empiris tentang kondisi faktual layanan bimbingan dan konseling khususnya layanan bimbingan kelompok di SMA yang ada di Kabupaten Kubu Raya yang terdiri dari 6 tahap yaitu studi pendahuluan, merumuskan program hipotetik, uji kelayakan program hipotetik, perbaikan program hipotetik, uji coba terbatas (Uji empirik), menyusun program akhir bimbingan kelompok tentang kesiapan berwirausaha.

Desain uji coba dalam penelitian pengembangan ini dilakukan untuk menghasilkan sebuah program bimbingan kelompok yang rasional, aplikatif serta teruji. Uji ahli dilakukan dengan melibatkan 3 orang pakar dalam layanan bimbingan dan konseling untuk memvalidasi program hipotetik agar menjadi sebuah program yang secara rasional mampu mempersiapkan wirausaha siswa. Uji praktisi dilakukan dengan melibatkan 10 orang praktisi dalam layanan bimbingan dan konseling untuk memvalidasi program hipotetik agar menjadi sebuah program yang praktis/mudah dalam pelaksanaannya nanti. Sedangkan uji coba terbatas akan dilakukan dengan desain eksperimen 10 siswa sebagai subjek penelitian diambil dengan teknik purposive sampling yaitu teknik pengumpulan sampel dengan pertimbangan tertentu. Subjek penelitian diberikan pre test untuk mengukur pemahaman kewirausahaan siswa, lalu diberikan perlakuan berupa 
layanan bimbingan kelompok, langkah selanjutnya adalah dilakukan post test dan kemudian membandingkan nilai pre test dan post test untuk melihat keefektifan bimbingan kelompok dalam pemahaman terhadap wirausaha.

Instrumen yang digunakan dalam penelitian ini terdiri dari pedoman wawancara dan observasi terhadap guru BK, lembar validasi ahli dan lembar validasi praktisi untuk mengumpulkan data kualitatif. Hasil dari penskoran dari observasi kesiapan berwirausaha siswa sebelum diberikan program bimbingan kelompok dan setelah diberikan program bimbingan kelompok untuk mengumpulkan data kuantitatif. Teknik analisis data yang digunakan adalah teknik analisis deskripsi kualitatif dan kuantitatif. Untuk membuktikan hipotesis dalam penelitian ini penulis melihat pemahaman siswa dalam berwirausaha sebelum dan sesudah diberikan perlakuan menggunakan rumus t-test dengan menggunakan bantuan perangkat lunak (software) SPSS 18.00 for Windows. Jika hasil uji menunjukkan hasil yang signifikan, maka program bimbingan kelompok tentang kesiapan berwirausaha pada siswa SMA dapat terlaksana dengan baik.

\section{HASIL DAN PEMBAHASAN}

Secara lebih rinci hasil studi pendahuluan tentang kesiapan berwirausaha siswa kelas XII SMA Negeri 1 Kubu Raya dapat dilihat pada tabel 1 di bawah ini:

Tabel 1 Kondisi Awal Kesiapan Berwirausaha Siswa Kelas XII

\begin{tabular}{|c|c|c|c|c|c|}
\hline No. & Aspek Variabel & Xideal & Xaktual & $\%$ & Kategori \\
\hline & Kesiapan berwirausaha & & & & \\
\hline & siswa kelas XI IPS Sekolah & 7140 & 004 & A & $C$ \\
\hline & Menengah Atas Negeri 9 & 1140 & 2840 & 40 & Cukup \\
\hline & Pontianak & & & & \\
\hline \multirow[t]{3}{*}{1.} & Kepemimpinan & & & & \\
\hline & Mampu mengambil & 1020 & 204 & 20 & $f^{\prime}$ \\
\hline & keputusan & & & & \\
\hline \multirow[t]{2}{*}{2.} & Berorientasi pada tugas dan & & & & \\
\hline & hasil & & & & \\
\hline
\end{tabular}




\begin{tabular}{|c|c|c|c|c|c|}
\hline \multirow{3}{*}{3} & Mampu bekerja keras & 816 & 308 & 38 & Cukup \\
\hline & $\begin{array}{l}\text { Berorientasi pada masa } \\
\text { depan }\end{array}$ & & & & \\
\hline & $\begin{array}{l}\text { Mampu menyusun } \\
\text { perencanaan }\end{array}$ & 1632 & 636 & 39 & Cukup \\
\hline \multirow[t]{2}{*}{4} & Kepercayaan diri & & & & \\
\hline & Adanya kepribadian mantap & 1836 & 737 & 40 & Cukup \\
\hline \multirow[t]{2}{*}{5} & Pengambilan resiko & & & & \\
\hline & $\begin{array}{l}\text { Kemampuan mengetahui } \\
\text { keputusan yang diambil }\end{array}$ & 1020 & 418 & 41 & Cukup \\
\hline \multirow[t]{3}{*}{6} & Keorisinilan & & & & \\
\hline & Mampu menciptakan & 816 & 363 & 40 & Cukun \\
\hline & Rata-rata keseluruhan aspek & 7140 & 2846 & 40 & Cukup \\
\hline
\end{tabular}

Berdasarkan tabel di atas maka dapat disimpulkan bahwa kondisi kesiapan berwirausaha siwa kelas XII SMA Negeri 1 Kubu Raya adalah sebesar 2846poin atau dengan presentase $40 \%$ dengan kategori cukup. Adapun aspek-aspeknya dapat dilihat: 1) Aspek kepemimpinan mencapai skor aktual 384 dari skor maksimal ideal 1020, berarti mencapai 38\% dari yang seharusnya. Dengan demikian kepemimpinan termasuk kategori "cukup". Ini dapat ditafsirkan bahwa siswa memiliki sikap mampu mengambil keputusan. 2) Aspek berorientasi pada tugas dan hasil mencapai skor aktual 308 dari skor maksimal ideal 816, berarti mencapai 38\% dari yang seharusnya. Dengan demikian berorientasi pada tugas dan hasil tergolong "cukup". Ini dapat ditafsirkan bahwa siswa memiliki sikap mampu bekerja keras. 3) Aspek berorientasi pada masa depan mencapai skor aktual 636 dari skor maksimal ideal 1632 berarti mencapai 39\% dari yang seharusnya. Dengan demikian berorientasi pada masa depan termasuk kategori "cukup". Ini dapat ditafsirkan bahwa siswa memiliki kemampuan menyusun perencanaan. 4) Aspek kepercayaan diri mencapai skor aktual 737 dari skor 
maksimal ideal 1836 berarti mencapai 40\% dari yang seharusnya. Dengan demikian kepercayaan diri termasuk kategori "cukup”. Ini dapat ditafsirkan bahwa siswa memiliki sikap adanya kepribadian yang mantap. 5) Aspek pengambilan resiko mencapai skor aktual 418 dari skor maksimal ideal 1020 berarti mencapai $41 \%$ dari yang seharusnya. Dengan demikian pengambilan resiko termasuk kategori "cukup". Ini dapat ditafsirkan bahwa siswa mempunyai kemampuan mengetahui keputusan yang diambil. 6) Aspek keorisinilan mencapai skor aktual 363 dari skor maksimal ideal 816 berarti mencapai 44\% dari yang seharusnya. Dengan demikian keorisinilan termasuk kategori "cukup". Ini dapat ditafsirkan bahwa siswa mampu menciptakan lapangan kerja sendiri.

Berdasarkan hasil studi pendahuluan peneliti menyusun model hipotetik program bimbingan kelompok tentang kesiapan berwirausaha pada siswa SMA Kubu Raya yaitu: (1) Rasional yang berisikan dasar pemikiran dan penjabaran secara khusus dan spesifik pentingnya proram bimbingan kelompok tentang kesiapan berwirausaha pada siswa SMA dengan masing-masing sub aspek yang akan ditingkatkan, (2) Visi dan misi program bimbingan kelompok yang diharapkan mampu memberikan kejelasan arah pencapaian secara umum program bimbingan kelompok pada siswa SMA, (3) Tujuan program bimbingan kelompok yang secara umum dan khusus menjabarkan tentang tujuan pelaksanaan kegiatan secara spesifik menyebutkan tujuan yang hendak dicapai berdasarkan indikator kesiapan siswa berwirausaha, (4) Isi program bimbingan kelompok secara spesifik menjabarkan mengenai ranah pribadi, sosial, belajar, dan karier yang hendak dicapai berdasarkan indikator kesiapan berwirausahaa pada siswa, Kemudian, (5) Pendukung sistem yang berisi tentang komponen pendukung sistem program bimbingan kelompok merupakan kegiatan manajemen yang diarahkan pada pengembangan program, pengembangan staf, penataan kebijakan, prosedur dan petunjuk teknis, dan (6) Tahapan program bimbingan kelompok berisi tentang tahap-tahap pelaksanaan, dimulai dari tahap permulaan, tahap peralihan, tahap kegitan dan tahap pengakhiran yang didalamnya memuat materi tentang kesiapan berwirausaha pada siswa sesuai dengan perkembangan masing-masing, Selain itu juga terdapat evaluasi dan tindak lanjut kegiatan melalui lembar observasi 
kesiapan berwirausaha anggota kelompok sehingga dapat terlihat hasil peningkatan dan pencapaian tujuan kegiatan program bimbingan kelompok untuk mempersiapkan siswa kelas XII dalam berwirausaha.

Program bimbingan kelompok dapat meningkatkan pemahaman kewirausahaan siswa. Hal tersebut dapat dilihat pada tabel 2 di bawah ini:

Tabel 2. Kondisi Akhir Kesiapan Berwirausaha Siswa Kelas XII

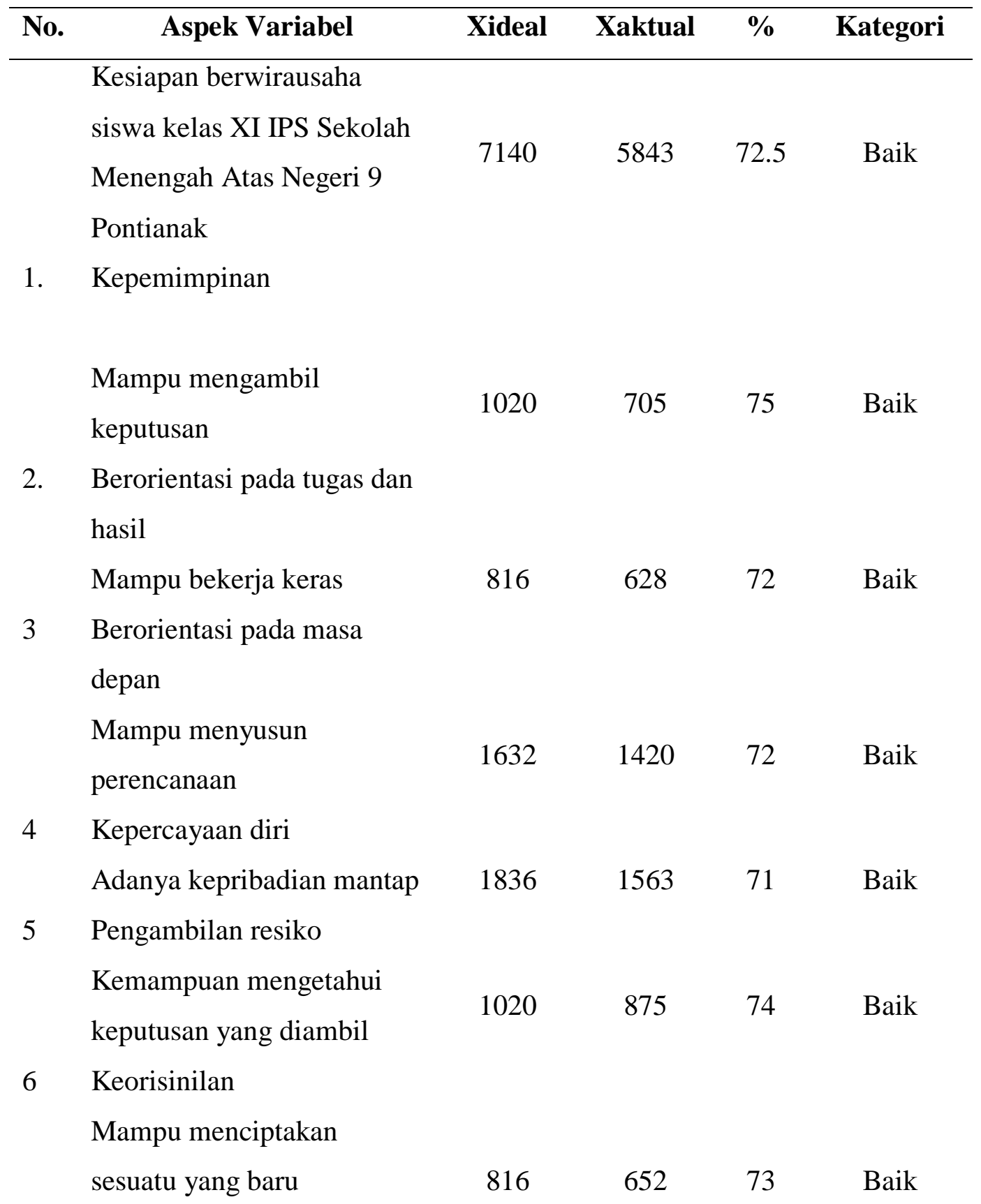


$\begin{array}{lllll}\text { Rata-rata keseluruhan aspek } & 7140 & 5843 \quad 72.5 & \text { Baik }\end{array}$

Berikut ini gambar perbedaaan kesiapan siswa berwirausaha sebelum dan sesudah dilaksanakan program bimbingan kelompok.

Gambar 1. Persentase Kesiapan Siswa Sebelum Dan Sesudah Diberikan Program Bimbingan Kelompok

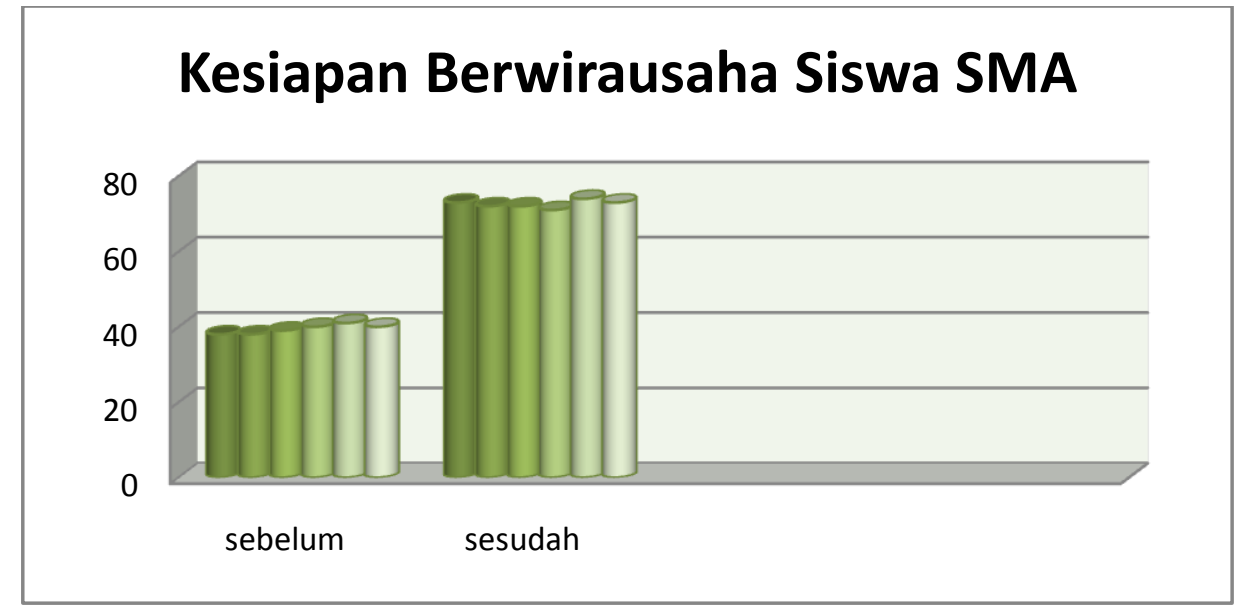

Dari gambar di atas, program bimbingan kelompok dapat meningkatkan kesiapan berwirausaha siswa SMA, hal tersebut dapat dilihat dari dari hasil sebelum dan sesudah dilaksanakannya program bimbingan kelompok.

\section{SIMPULAN}

Kesiapan berwirausaha pada siswa SMA dari aspek kepemimpinan, mampu mengambil keputusan, berorientasi pada masa depan, kepercayaan diri, pengambilan resiko, dan keorisinilan dengan rata-rata persentase $40 \%$ katageri cukup, rancangan program bimbingan kelompokter diri dari 6 komponen, yakni: (1) Rasional, (2) Visi dan Misi Program Bimbingan Kelompok, (3) TujuanProgram Bimbingan Kelompok, (4) Isi Program Bimbingan Kelompok, (5) Pendukung Sistem Program Bimbingan Kelompok, dan (6) Tahapan Bimbingan Kelompok, kelayakan program tersebut telah divalidasi oleh 3 pakar bimbingan dan konseling serta 10 praktisi yaitu guru yang menangani kelas XII. Hasil uji kelayakan menunjukkan bahwa program yang dirancang layak untuk 
diimplementasikan di lapangan, sehingga program bimbingan kelompok secara efektif dapat meningkatkan kesiapan siswa berwirausaha.

\section{DAFTAR PUSTAKA}

Aydin, D. 2009. Efectiveness Of A Group Guidance Program On Realistic Study Field Choice Among First Year High School Students. Jurnal of Education, Volume 5 No. 1. Hal 67-84. (diunduh 1 Januari 2017).

Driessens, K. 2004. Integrating Guidance into Relational Reinforcement Learning. Jurnal of Education, Volume 34 No. 57. Hal 271-304. (diunduh 1 Januari 2017).

Dodi Priyatmo. 2013. Tesis: Model Bimbingan Kelompok Berbasis Nilai Budaya Suku Tolaki Untuk Meningkatkan Keterampilan Sosial Siswa. Semarang: UNNES.

Hellen, C. \& Kuruvilla Joseph. 2011. Effectiveness Of Group Counseling On The Level Of Self-Esteem Of Adolescent School Girls. Jurnal of Education, Volume 2 No.3. Hal 28-32. (diunduh 2 Januari 2017).

Hoifodt, S. O. \& Talseth, G. A. 2006. A Qualitative Study Of The Learning Processes In Young Physician Streating Suicidal Patients: From Insecurity To Personal Pattern Knowledge and Self-Confidence. Jurnal of Education, Volume 10 No. 23. Hal 134-143. (diunduh 2 Januari 2017).

Jerizal. 2012. Tesis: Model Bimbingan Kelompok Berbasis Budaya Hibua Lamo Untuk Meningkatkan Kecerdasan Emosional Siswa. Semarang: UNNES.

Kasmir 2014. Kewirausahaan: Teori dan Praktek. Jakarta: PT Ikrar Mandiri Abadi.

Nandang. 2008. Modul: Pelatihan Teknik- Teknik Bimbingan Kelompok Menggunakan Latihan Kelompok. Bandung: UPI Bandung.

Nuraniningsih. 2011. Tesis: Bimbingan Kelompok Untuk Meningkatkan Kecerdasan Emosional Siswa. Semarang: UNNES.

Sue. 2008. Jurnal: Therapeuitic Factorsin Group Counseling: Implications for Audiologic Rehabilitation. Brooks/ Cole Publishing Company: USA.

Wibowo. 2005. Konseling Kelompok Perkembangan. Semarang: UPT Unnes Press. 